\title{
Hydrochloric acid-treated Bacillus subtilis ghosts induce IL-1 beta, IL-6, and TNF-alpha in murine macrophage
}

\author{
Young-Min Kim ${ }^{1} \cdot$ Kwang-Su Lee $^{1} \cdot$ Won-Mun Kim ${ }^{1} \cdot$ Min Kim $^{1} \cdot$ Han-Oh Park ${ }^{3} \cdot$ Chang Won Choi ${ }^{1} \cdot$ Joong-Soo Han ${ }^{2}$. \\ Shin-Young Park ${ }^{2}$ (I) Ki-Sung Lee ${ }^{1}$
}

Accepted: 3 January 2022 / Published online: 18 January 2022

(c) The Author(s) 2022

\begin{abstract}
Background Bacterial ghosts (BGs) are empty cell envelopes commonly generated using Gram-negative bacteria; they represent a potential platform for efficient adjuvant and vaccine delivery systems. However, the efficient production of BGs from bacteria in a short period of time is challenging.

Objective The purpose of this study was to investigate the possibility of producing BGs in the Gram-positive Bacillus subtilis using various chemicals, and the potential application of BGs as a novel immunomodulatory agent.

Results In this study, Bacillus subtilis ghosts (BSGs) were generated, for the first time to the best of our knowledge, using the minimum inhibitory concentration (MIC) of hydrochloric acid $(\mathrm{HCl} ; 6.25 \mathrm{mg} / \mathrm{mL})$, sulfuric acid $\left(\mathrm{H}_{2} \mathrm{SO}_{4} ; 3.125 \mathrm{mg} /\right.$ $\mathrm{mL})$, and nitric acid $\left(\mathrm{HNO}_{3} ; 6.25 \mathrm{mg} / \mathrm{mL}\right)$. Among the BSGs generated using these chemicals, HCl-induced BSGs were completely DNA-free as confirmed by real-time polymerase chain reaction. Scanning electron microscopy showed the formation of transmembrane lysis tunnel structures in HCl-induced BSGs. Murine macrophages exposed to the HCl-induced BSGs at a concentration of $1 \times 10^{5} \mathrm{CFU} / \mathrm{mL}$ showed a cell viability of $97.8 \%$. Additionally, $\mathrm{HCl}$-induced BSGs upregulated the expression of pro-inflammatory cytokines including interleukin (IL)-1 $\beta$, tumor necrosis factor alpha, and IL-6. Furthermore, we found differences in the protein expression profiles between intact live bacteria and BSGs using two-dimensional electrophoresis coupled with peptide mass fingerprinting/matrix-assisted laser desorption/ionization-time of flight mass spectrometry analysis.
\end{abstract}

Conclusion These data suggest that the HCl-induced BSGs may be potentially safe and effective candidates for inactivated bacterial vaccines and/or immunostimulants.

Keywords Bacillus subtilis $\cdot$ Bacterial ghosts $\cdot$ Hydrochloric acid $\cdot$ Macrophages $\cdot$ Cytokines

\section{Introduction}

Shin-Young Park

ttokttoki@hanyang.ac.kr

Ki-Sung Lee

kslee@pcu.ac.kr

1 Department of Biology and Medicinal Science, Pai Chai University, Daejeon, Republic of Korea

2 Biomedical Research Institute and Department of Biochemistry and Molecular Biology, College of Medicine, Hanyang University, Seoul, Republic of Korea

3 New Drug R\&D Center, Bioneer Corporation, Daejeon, Republic of Korea
Bacterial ghosts (BGs) are empty bacterial envelopes of Gram-negative bacteria produced via controlled expression of the cloned lysis gene $E$ of bacteriophage phi174 (Hajam et al. 2015) that forms transmembrane lysis tunnel structures on bacterial cell surfaces (Eko et al. 2000). Electron microscopic analyses have revealed non-living whole cell envelopes that lack cytoplasmic contents but maintain cellular morphology similar to that of native bacteria, where the entire cell surface structures contain outer membrane proteins, adhesion proteins, lipids, and lipopolysaccharides (LPS) (Huter et al. 1999). BGs represent a potential platform for efficient adjuvant and vaccine delivery systems (Hajam et al. 2017). This approach shows promising results for eliciting immune responses against specific infections 
in natural hosts as well as in experimental animals (Lubitz et al. 2009). Moreover, the use of whole cells of killed bacteria as a potential vaccine may result in the introduction of antibiotic resistance genes or pathogenic islands into host microbes (Frosch and Meyer 1992). These properties make BGs an attractive tool for vaccine development and antigen delivery systems in both humans and animals (Hajam et al. 2017).

The bacteriophage phi174 lysis gene $E$-induced BGs have been shown to provide efficient protection against specific infections (Tu et al. 2010). However, there are a few disadvantages of this method, such as its application to only Gram-negative bacteria and the potential difficulties in attaining a $100 \%$ lysis rate of BGs in a short period (Vinod et al. 2015). Alternatively, novel approaches have been demonstrated for Escherichia coli BG preparation using the minimum inhibitory concentration (MIC) and minimum growth concentration of various chemicals (Amara et al. 2013). This protocol requires a short period to generate BGs without any potential risks and is a simple process. Notably, it can be applied to both Gram-positive and Gram-negative bacteria (Vinod et al. 2014). Recently, sodium hydroxide (NaOH)induced BGs have been produced from a Gram-positive bacterium (Staphylococcus aureus) (Vinod et al. 2014) and a Gram-negative bacterium (Salmonella enteriditis) (Vinod et al. 2015). Although certain surface structures on BGs may be modified or lost due to $\mathrm{NaOH}$ (Park, et al. 2016), the $\mathrm{NaOH}$-induced $\mathrm{BGs}$ provide efficient protection against specific infections (Vinod et al. 2017).

Bacillus subtilis is a bacterium belonging to the genus Bacillus mainly found in soil and is a Gram-positive sporeforming bacterium (Dijl and Hecker 2013). It is also known to be a fermentation microorganism and is used as a microbial agent (Stein 2005). Lactic acid bacteria represent a good source of food additives for immunity enhancement, and they also act as a probiotic agent. However, B. subtilis can sometimes cause toxicity, including food poisoning or hepatotoxicity (Poudel et al. 2016). To solve this problem, we produced chemically induced B. subtilis ghosts (BSGs), which are dead cells, thereby completely eliminating the toxicity of living cells. In this study, BSGs were successfully produced via chemical-mediated lysis. We investigated the cytotoxic effect of hydrochloric acid $(\mathrm{HCl})$-induced BSGs on murine macrophage RAW 264.7 cells and their immunomodulatory activities based on the mRNA expression of pro-inflammatory cytokines. Moreover, we analyzed the differences in the protein expression profiles between intact live bacteria and BSGs using two-dimensional electrophoresis (2-DE) and identified the differentially expressed proteins using peptide mass fingerprinting (PMF)/matrix-assisted laser desorption ionization-time of flight (MALDI-TOF) mass spectrometry analysis. This study evaluated the potential efficacy of a chemical-induced BSG vaccine or adjuvant and its ability to induce protective immune responses against pathogens.

\section{Materials and methods}

\section{Bacterial strain and culture conditions}

Bacillus subtilis EBM13 (Korean collection for type cultures: 0984BP) was used to produce the BGs. B. subtilis was grown in Luria-Bertani broth (LB, $\mathrm{pH}$ 7.0) in a shaking incubator $(200 \mathrm{rpm})$ at $36{ }^{\circ} \mathrm{C}$. Bacterial cell growth and lysis were monitored by measuring the absorbance at $600 \mathrm{~nm}$ $\left(\mathrm{OD}_{600}\right)$ using a spectrophotometer. The colony-forming units (CFUs) were enumerated as described previously (Park et al. 2016).

\section{Chemical reagents and determination of MIC}

Bacillus subtilis cultures were grown to $1 \times 10^{9} \mathrm{CFU} / \mathrm{mL}$ concentrations in LB broth. Hydrochloric acid $(\mathrm{HCl})$, nitric acid $\left(\mathrm{HNO}_{3}\right)$, and sulfuric acid $\left(\mathrm{H}_{2} \mathrm{SO}_{4}\right)$ were purchased from Sigma-Aldrich (St. Louis, MO, USA). The lowest concentration of each used chemical was $50 \mathrm{mg} / \mathrm{mL}$. The MIC was determined using the two-fold dilution method (Stickel et al. 2009) with certain modifications. A serially diluted solution of each chemical was added to the bacterial culture, followed by incubation at $36^{\circ} \mathrm{C}$ for $18 \mathrm{~h}$. The MICs of the different chemicals were determined in triplicate. To validate the MIC values, the culture that showed no growth was further tested by spreading $100 \mu \mathrm{L}$ of the culture onto LB agar plates, followed by incubation at $36^{\circ} \mathrm{C}$ for $24 \mathrm{~h}$.

\section{Production of BSGs}

The biomass of $B$. subtilis cells cultured for $72 \mathrm{~h}$ was pelleted via centrifugation $\left(12,000 \times g\right.$ for $15 \mathrm{~min}$ at $\left.4{ }^{\circ} \mathrm{C}\right)$, resuspended twice in phosphate-buffered saline (PBS; $5 \mathrm{mM}$ $\mathrm{Na}_{2} \mathrm{HPO}_{4}, 150 \mathrm{mM} \mathrm{NaCl}, 5 \mathrm{mM} \mathrm{KH} \mathrm{PO}_{4}, \mathrm{pH} 7.0$ ), and used at a final concentration of $1 \times 10^{9} \mathrm{CFU} / \mathrm{mL} .1 \mathrm{ml}$ of stock solutions $(5 x)$ of the different chemicals prepared based on the MIC values was added to $1.8 \mathrm{~mL}$ of the bacterial suspension and incubated for $60 \mathrm{~min}$ at $36^{\circ} \mathrm{C}$. The rates of cell lysis of the untreated control and bacterial samples treated with the respective chemicals were ascertained at various time points using a standard plating procedure. At the end of the lysis process, the BSGs were harvested via centrifugation $\left(12,000 \times g\right.$ for $15 \mathrm{~min}$ at $\left.4{ }^{\circ} \mathrm{C}\right)$ and washed thrice with PBS. Finally, cell pellets were re-suspended in PBS and stored at $4{ }^{\circ} \mathrm{C}$ until use. 


\section{Isolation and quantification of DNA using real-time polymerase chain reaction (PCR)}

To confirm the presence of DNA-free BSGs of B. subtilis cells, the bacterial cells were treated with the MICs of different chemicals; non-treated cells were used as the control. Genomic DNA was extracted using a bacterial genomic DNA isolation kit (iNtRON Biotechnology, Gyeonggi-do, Korea). Electrophoresis was performed using a $0.8 \%$ agarose gel, and single-step quantitative real-time PCR was performed using the SyBr Green detection system. The 16S rRNA of $B$. subtilis was amplified using specific primers (Table 1). Each $20 \mu \mathrm{L}$ real-time PCR reaction mix comprised $10 \mu \mathrm{L}$ of $2 \times \mathrm{SyBr}$ Green qPCR Master Mix (Agilent Technologies, Santa Clara, CA, USA), $0.8 \mu \mathrm{L}$ of each primer $(10 \mathrm{pmol} / \mu \mathrm{L}$ ), $0.2 \mu \mathrm{L}$ of Rox dye, $7.2 \mu \mathrm{L}$ of sterilized distilled water, and $1 \mu \mathrm{L}$ of template DNA. The thermal cycling conditions were as follows: an initial denaturation at $98^{\circ} \mathrm{C}$ for $7 \mathrm{~min}$ followed by 39 cycles at $98{ }^{\circ} \mathrm{C}$ for $10 \mathrm{~s}, 56{ }^{\circ} \mathrm{C}$ for $30 \mathrm{~s}$, and $72{ }^{\circ} \mathrm{C}$ for $30 \mathrm{~min}$ in a Stratagene Mx3000P real-time PCR instrument (Agilent Technologies). Negative control TE buffer was included at the same time. All reactions were performed in triplicate. The experiments were analyzed using auto-baseline and thresholds chosen from the real-time PCR amplification. The Ct value and the DeltaRn $(\mathrm{dRn})$ were used for data analysis.

\section{Cytotoxicity of macrophages exposed to intact bacteria and BSGs}

Murine macrophages (RAW 264.7) were purchased from the Korean Cell Line Bank (ID: 40071; Seoul, South Korea). Cells were cultured in 96-well plates (BD Falcon, Franklin Lakes, USA). The macrophages $\left(1 \times 10^{5}\right.$ cells $\left./ \mathrm{mL}\right)$ were treated with $\mathrm{HCl}$-induced BSGs and live non-treated cells at various doses $\left(1 \times 10^{5}, 10^{6}, 10^{7}, 10^{8}\right.$, and $\left.10^{9} \mathrm{CFU} / \mathrm{mL}\right)$

Table 1 Primer sequences and fragment sizes of the targeted genes in real-time PCR

\begin{tabular}{|c|c|c|}
\hline Gene & Orientation & Primer sequences $\left(5^{`}-3^{`}\right)$ \\
\hline \multirow{2}{*}{$\begin{array}{l}16 \text { s rRNA } \\
(492 \mathrm{bp})\end{array}$} & forward & 5`AGAGTTTGATCCTGGCTCAG-3` \\
\hline & reverse & 5`ATTACCGCGGCTGCTGG-3` \\
\hline \multirow[t]{2}{*}{ IL-1 $\beta$ (284 bp) } & forward & $\begin{array}{l}5 \text {-GACCTTCCAGGATGAGGACA } \\
-3\end{array}$ \\
\hline & reverse & 5`AGGCCACAGGTATTTTGTCG -3` \\
\hline \multirow[t]{2}{*}{$\begin{array}{l}\text { IL-6 } \\
(159 \text { bp) }\end{array}$} & forward & $\begin{array}{l}\text { 5-AGTTTGCCTTCTTGGGACTGA } \\
-3\end{array}$ \\
\hline & reverse & 5`TCCACGATTTCCCAGAGAAC-3` \\
\hline \multirow{2}{*}{$\begin{array}{l}\text { TNF- } \alpha \\
\text { (285 bp) }\end{array}$} & forward & 5`CCGATGGGTTGTACCTTGTC -3` \\
\hline & reverse & 5`CGGACTCCGCAAAGTCTAAG-3` \\
\hline \multirow{2}{*}{$\begin{array}{l}\text { GAPDH } \\
(165 \mathrm{bp})\end{array}$} & forward & 5`-GGCATTGCTCTCAATGACAA-3` \\
\hline & reverse & 5`AGGGCCTCTCTCTTGCTCTC-3` \\
\hline
\end{tabular}

at $37{ }^{\circ} \mathrm{C}$ for $24 \mathrm{~h}$ in $5 \% \mathrm{CO}_{2}$ and $95 \%$ air; LPS $(5 \mu \mathrm{g} / \mathrm{mL})$ and PBS were used as the positive and negative controls, respectively. Cell Counting Kit-8 (CCK-8; Sigma-Aldrich) was used to determine cell density. Absorbance (450 nm) was measured using a microplate reader (BioRad Laboratories, Inc., Hercules, CA, USA) and the experiment was performed in triplicate. Cytotoxic activity was calculated using the following formula: cytotoxicity $(\%)=\left(1-A_{450}\right.$ of target cells $/ A_{450}$ of control cells) $\times 100$, where $A_{450}=$ absorbance at $450 \mathrm{~nm}$.

\section{Quantitative analysis of cytokine mRNA expression via quantitative reverse transcription (RT)-qPCR}

Raw 264.7 cells were cultured in 24-well plates and treated with the intact $B$. subtilis cells and BSGs separately at a concentration of $1 \times 10^{5} \mathrm{CFU} / \mathrm{mL}$. After $24 \mathrm{~h}$ of stimulation, total RNA was extracted using the RNAiso Plus kit (Takara Bio Inc., Ohtsu, Japan). cDNA was synthesized via the reverse transcription of $300 \mathrm{ng}$ of purified total RNA using the GoScript ${ }^{\mathrm{TM}}$ Reverse Transcriptase kit and random primers (Promega Corporation, Madison, WI, USA). qPCR was performed using a SensiFAST ${ }^{\mathrm{TM}}$ SYBR No-ROX Kit (Bioline, London, UK) on a Stratagene Mx3000P real-time PCR instrument (Agilent Technologies). The primers used for RT-qPCR are listed in Table 1. Thermocycling conditions were $95{ }^{\circ} \mathrm{C}$ for $5 \mathrm{~min}$ followed by 39 cycles of $95^{\circ} \mathrm{C}$ for $30 \mathrm{~s}$ and $58{ }^{\circ} \mathrm{C}$ for $1 \mathrm{~min}$. Relative quantification was performed using the $2^{-\Delta \Delta \mathrm{Ct}}$ method.

\section{Scanning electron microscopy (SEM)}

Morphological features of the $\mathrm{HCl}$-induced BSGs and native $B$. subtilis cells were analyzed via SEM as previously described (Fernandes et al. 1985). Cells were fixed with $2.0 \%$ glutaraldehyde in $0.15 \mathrm{M}$ phosphate buffer ( $\mathrm{pH} 7.0)$ at $4{ }^{\circ} \mathrm{C}$ for $2 \mathrm{~h}$. Subsequently, the cells were washed thrice with the same buffer and post-fixed in $1.1 \%$ osmium tetroxide at $4{ }^{\circ} \mathrm{C}$ for $2 \mathrm{~h}$. The fixed cells were then dehydrated using increasing ethanol concentrations (10-100\%) and dried using liquid carbon dioxide. Thereafter, the samples were sputtered with gold-palladium using a high-resolution sputtering system before scanning. Electron micrograph images were examined using a Leo 1455VP scanning electron microscope (Korea Basic Science Institute, Daejeon, Korea).

\section{2-DE and image analysis}

Urea, thiourea, 3-[(3-cholamidopropyl) dimethyammonio]1-propanesulfonate (CHAPS), Bradford solution, dithiothreitol (DTT), benzamidine, acrylamide, iodoacetamide, bis-acrylamide acetonitrile, sodium dodecyl sulfate (SDS), and trifluoroacetic acid were obtained from Sigma-Aldrich 
(electrophoresis grade, ACS reagents, ultrapure). Pharmalyte ( $\mathrm{pH} 3.5-10)$ was purchased from Amersham Biosciences (Little Chalfont, UK) and IPG DryStrips (pH 4-10 NL) were purchased from Genomine Inc. (Pohang, Kyungbuk, Korea). Modified porcine trypsin (sequencing grade) was purchased from Promega. For protein sample preparation, the cultured cell pellets were washed twice with PBS and sonicated for $8 \mathrm{~s}$ using Sonoplus (Bandelin electronic, Berlin, Germany). Samples were homogenized using a motor-driven homogenizer (PowerGen125, Fisher Scientific, Rockford, IL, USA) in a sample lysis solution composed of $2 \mathrm{M}$ thiourea containing 4\% (w/v) CHAPS, $8 \mathrm{M}$ urea, $2 \%(\mathrm{v} / \mathrm{v})$ pharmalyte, $1 \%(\mathrm{w} / \mathrm{v})$ DTT, and $1 \mathrm{mM}$ benzamidine. Freezing and thawing steps for samples were repeated six times in one day. A bead beater was used for lysis of rigid cells. Proteins were extracted for $1 \mathrm{~h}$ with vortexing. After centrifugation at $13,000 \times g$ for $1.5 \mathrm{~h}$ at $15{ }^{\circ} \mathrm{C}$, the insoluble material was discarded and the soluble fraction was used for two-dimensional gel electrophoresis (2D PAGE).

For the 2D PAGE process, IPG dry strips (pH 4-10 NL IPG, $24 \mathrm{~cm}$ ) were equilibrated for $14 \mathrm{~h}$ with $8 \mathrm{M}$ urea and $2 \mathrm{M}$ thiourea containing $4 \%$ CHAPS, $1 \%$ pharmalyte, and $1 \%$ DTT loaded with $300 \mu \mathrm{g}$ of sample. Isoelectric focusing (IEF) was performed at $18{ }^{\circ} \mathrm{C}$ using a Multiphor II electrophoresis unit and EPS $3501 \mathrm{XL}$ power supply (Amersham Biosciences) by following the manufacturer's instructions. For IEF, the voltage was linearly raised from 200 to $3000 \mathrm{~V}$ during $3.5 \mathrm{~h}$ for sample entry followed by a constant $3000 \mathrm{~V}$, with focusing complete after $96 \mathrm{kVh}$. The strips were incubated for $20 \mathrm{~min}$ in equilibration buffer ( $30 \mathrm{mM}$ Tris-Cl pH 6.8 containing $7 \mathrm{M}$ urea, $1 \%$ SDS, and $30 \%$ glycerol), first with $2 \%$ DTT and subsequently with $2.5 \%$ iodoacetamide. Equilibrated strips were inserted into SDS-PAGE gels $(20 \times 24 \mathrm{~cm}, 11-16 \%)$. SDS-PAGE was performed using a Hoefer DALT 2D system (Amersham Biosciences) following the manufacturer's instructions. The $2 \mathrm{D}$ gels were run at $22{ }^{\circ} \mathrm{C}$ for $1500 \mathrm{Vh}$. Subsequently, the $2 \mathrm{D}$ gels were silverstained as described by Oakley et al. (Zhu et al. 2012); however, the fixing and sensitization step using glutaraldehyde was omitted. Quantitative analysis of the images was performed using the PDQuest 7 software (BioRad). All matched spots were checked manually. Spots with a significant differential abundance were selected based on two criteria: $t$ test $<0.05$ and fold change $>2.0$. Selected protein spots showing significant differences were identified via mass spectrometry.

\section{PMF/MALDI-TOF analysis of differentially expressed proteins (spots)}

$\alpha$-Cyano-4-hydroxycinnamic acid (CHCA), 4-Sulfophenyl isothiocyanate, ammonium bicarbonate, and sodium bicarbonate were purchased from Sigma-Aldrich. PMF was performed as follows: for protein identification via PMF, the protein spots were excised, digested with trypsin (Promega), mixed with CHCA in $60 \%$ acetonitrile/ $0.15 \%$ trifluoroacetic acid, and subjected to MALDI-TOF analysis (Microflex LRF 20, Bruker Daltonics, Bremen, Germany) as described by Fernandez et al. (Oakley et al. 1980). The peak list was investigated using Flex Analysis 3.0. The threshold used for peak-picking was as follows: 300 for minimum resolution of monoisotopic mass, 3 for $\mathrm{S} / \mathrm{N}$. For protein identification, MASCOT (Matrix Science Ltd., London, UK) search program was used. The following parameters were used for the database search: iodoacetamide (Cys) as a complete modification, trypsin as the cleaving enzyme, oxidation (Met) as a partial modification, monoisotopic masses, and a mass tolerance of $\pm 0.2 \mathrm{Da}$. The PMF acceptance criteria used was probability scoring.

\section{Statistical analysis}

In each experiment, all measurements were performed at least in triplicate. All quantitative data are expressed as the mean \pm standard error of the mean. Data were analyzed using a two-tailed Student's $t$ test, and values of $p<0.05$ were considered significant. Graphing was conducted with SigmaPlot 12.5 (Systat Software, Inc., San Jose, CA, USA).

\section{Results}

\section{Production of chemical-induced BGs}

To produce the chemical-induced BGs, the MICs of $\mathrm{HCl}$, $\mathrm{H}_{2} \mathrm{SO}_{4}$, and $\mathrm{HNO}_{3}$ against $B$. subtilis were first determined using the two-fold broth dilution method (Fig. 1A and Table 2). We found that B. subtilis did not form any colonies on LB agar plates on treatment with the chemicals at their corresponding MICs (Fig. 1B), indicating that the MIC of the BGs was determined based on cell death within $60 \mathrm{~min}$ of exposure to each chemical. Consequently, this concentration was used to generate non-living BGs.

\section{Determination of DNA-free BSGs}

A careful consideration of the chemicals used to induce complete DNA-free BGs is necessary to prevent the risk of toxicity. As shown in Fig. 2A, B. subtilis cells treated with the $\mathrm{MIC}$ of $\mathrm{HCl}, \mathrm{H}_{2} \mathrm{SO}_{4}$, or $\mathrm{HNO}_{3}$ showed no genomic DNA bands. To confirm this result, we performed qPCR analysis of the BSGs induced by the chemicals (Fig. 2B). Among them, only $\mathrm{HCl}$-induced BSGs showed a complete absence of DNA that was approximately equivalent to the negative control TE buffer (Fig. 2C). This result suggested that DNA-free BSGs were successfully induced using $\mathrm{HCl}$ 

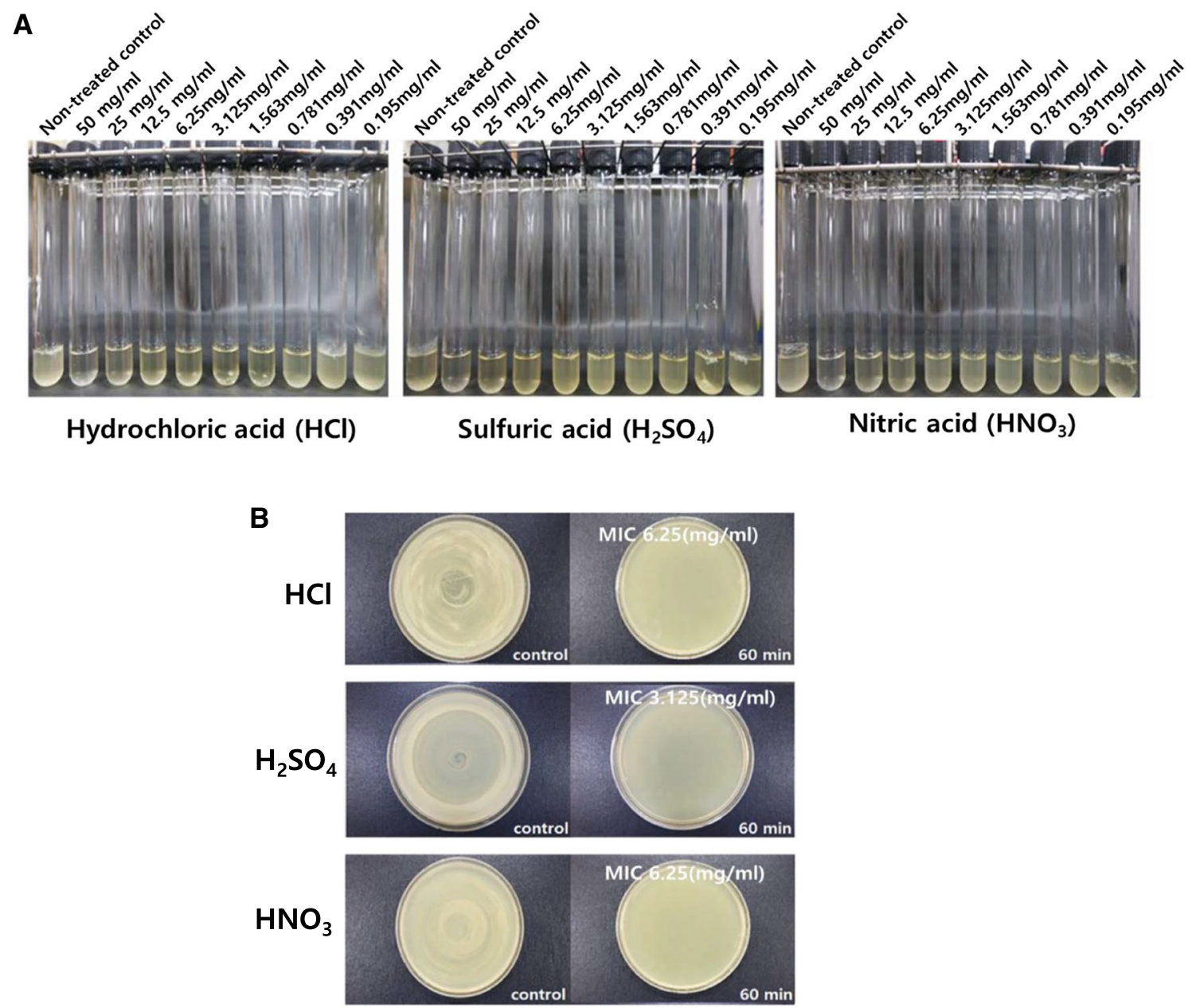

Fig. 1 Determination of MIC of different chemicals on Bacillus subtilis bacterial cells. (A) Tubes 1-9 represent bacterial culture treated with respective chemicals at 0 (non-treated control), 50, 25, 12.5,

Table 2 Minimum inhibitory concentration (MIC) of chemicals treated into Bacillus Subtilis culture medium

\begin{tabular}{lll}
\hline Chemical & MIC $(\mathrm{mg} / \mathrm{ml})$ & $\begin{array}{l}\mathrm{pH} \\
\text { (media- } \\
\text { MRS) }\end{array}$ \\
\hline Hydrochloric acid & $6.25(\mathrm{mg} / \mathrm{ml})$ & 1.44 \\
Sulfuric acid & $3.125(\mathrm{mg} / \mathrm{ml})$ & 1.46 \\
Nitric acid & $6.25(\mathrm{mg} / \mathrm{ml})$ & 1.40 \\
\hline
\end{tabular}

at $\mathrm{MIC}$, and that $\mathrm{HCl}$ was the most effective chemical for the production of BSGs.

\section{Cytotoxicity analysis of murine macrophages exposed to BSGs}

The cytotoxicity was compared by analyzing the viability of murine macrophage RAW 264.7 cells exposed to Dulbecco's modified Eagle's medium (DMEM), LPS, intact
$6.25,3.125,1.563,0.781,0.391$, and $0.195 \mathrm{mg} / \mathrm{ml}$, respectively. (B) Bacillus subtilis bacterial cells treated with MIC of the different chemicals showed no viability

B. subtilis (BS), and $\mathrm{HCl}$-induced BSGs (Fig. 3A). Since LPS is well known to activate macrophages (Rossol et al. 2011), we used LPS to compare the cytotoxic effects of $\mathrm{HCl}-$ induced BSGs on macrophages. The tested concentration of LPS $(5 \mu \mathrm{g} / \mathrm{mL})$ was enough to induce macrophage activation; the macrophages showed a cell viability of $93.3 \%$. The macrophages exposed to $\mathrm{HCl}$-induced BSG5 $\left(1 \times 10^{5} \mathrm{CFU} /\right.$ $\mathrm{mL})$ showed a higher viability than those treated with the other BSGs (BSG4: $1 \times 10^{6}$, BSG3: $1 \times 10^{7}$, BSG2: $1 \times 10^{8}$, and BSG1: $1 \times 10^{9} \mathrm{CFU} / \mathrm{mL}$ ); the results were similar to those of macrophages exposed to BS under the same concentration range. This suggested that the $\mathrm{MIC}$ of $\mathrm{HCl}$ was not associated with a complete reduction in the cytotoxic effect of BS. Macrophages exposed to BSGs at $1 \times 10^{5} \mathrm{CFU} /$ $\mathrm{mL}$ concentration showed the highest cell viability (97.9\%), whereas those exposed to BSGs at $1 \times 10^{9} \mathrm{CFU} / \mathrm{mL}$ showed the lowest cell viability (75.1\%) compared to the results of other concentrations. Since treatment using the BSGs and BS showed the highest cell viability at a concentration of 


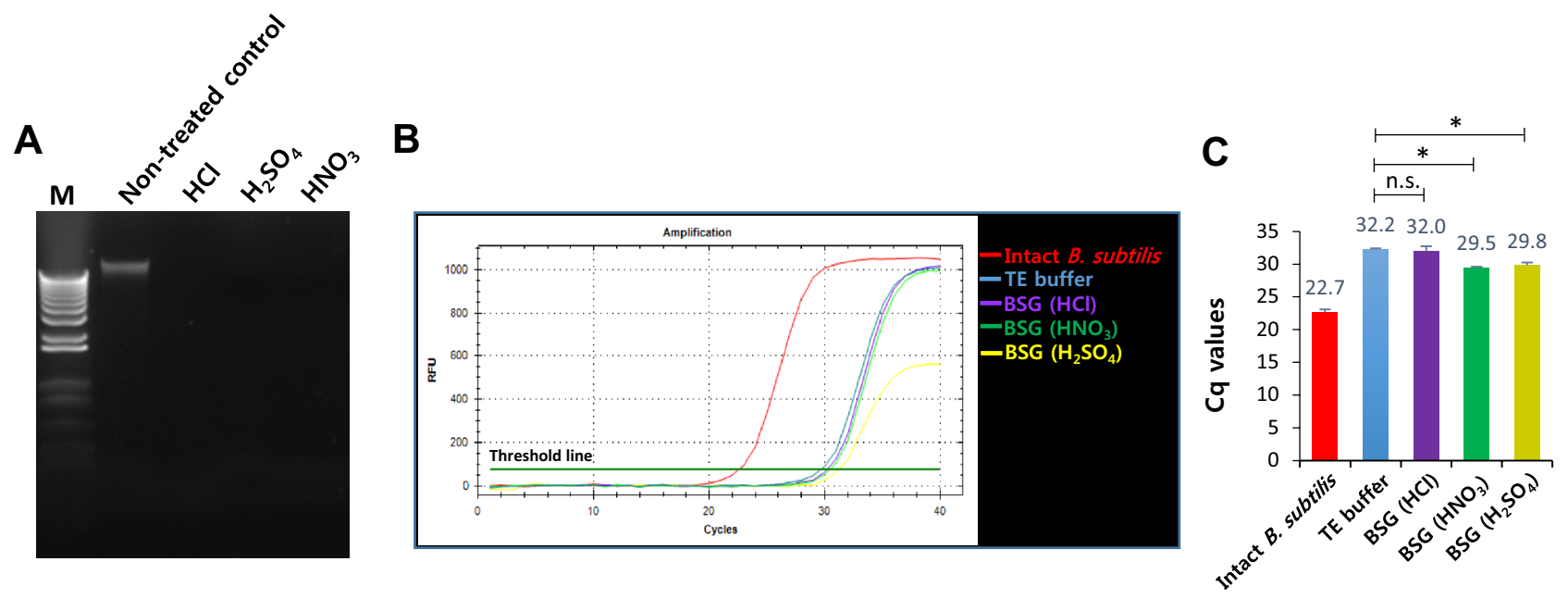

Fig. 2 Determination of the most effective chemical for the preparation of DNA-free BSGs. (A) Agarose gel (0.8\%) electrophoresis of genomic DNA extracted from BSGs treated with the MICs of $\mathrm{HCl}$, $\mathrm{H}_{2} \mathrm{SO}_{4}$, and $\mathrm{HNO}_{3}$, for 60 min. $\mathrm{M}, 1 \mathrm{~kb}$ DNA ladder. (B, C) DNA quantity of the respective BSG was compared with that of intact $B$.

$1 \times 10^{5} \mathrm{CFU} / \mathrm{mL}$, we used this concentration in the following experiments.

\section{Effect of BG treatment on cytokine expression in macrophages}

We analyzed the mRNA expression of pro-inflammatory cytokines in macrophages exposed to $\mathrm{HCl}$-induced BSGs and LPS to determine the immunomodulatory activity of BSGs. LPS is responsible for the observed activation of macrophages leading to cytokine production, cytotoxicity, and oxidative stress (Rossol et al. 2011; Soromou, et al. 2012). Therefore, LPS was used as a positive control for cytokine production of macrophages to check whether BSGs produce cytokines in the present study. In the macrophages exposed to the BSGs $\left(1 \times 10^{5} \mathrm{CFU} / \mathrm{mL}\right)$, the mRNA expression of IL- $1 \beta$, IL- 6 , and TNF- $\alpha$ was significantly increased compared to that in the non-treated control cells (Fig. 3B-D). Collectively, the results suggested that $\mathrm{HCl}$-induced BSGs might have activated the macrophages to secrete pro-inflammatory cytokines and might act as promising inflammatory regulators of mammalian cells.

\section{Morphology of $\mathrm{HCl}$-induced BSGs based on SEM}

We investigated the formation of chemical-induced BSGs and BS using SEM (Fig. 4). When compared with an electron micrograph of untreated BS (Fig. 4A), the electron micrograph of BSGs showed the formation of a transmembrane lysis tunnel structure on the surface of the BSGs (Fig. 4B), indicating that a specific concentration of $\mathrm{HCl}$ subtilis (positive control) and TE buffer (negative control). A standard curve for the absolute quantification of bacterial DNA was generated based on the dilution of genomic DNA of B. subtilis in a solution containing $1 \mathrm{ng}$ DNA. All experiments were performed in triplicate $(n=3) . * p<0.05$ compared with TE buffer (negative control)

induced sufficient formation of the transmembrane tunnel structure on the cell surface. This indicated that the cytoplasmic and genetic contents might have been expelled, thereby turning the cell into an empty cell envelope. Except for these pores, BSGs exhibited normal cellular morphology including all cell surface structures that were unaffected by the lysis process.

\section{Identification of differential protein expression between $\mathrm{BS}$ and $\mathrm{HCl}$-induced BSGs}

The differences in protein patterns and profiles between the BS control and the HCl-induced BSGs were observed in the 2-DE gel (Fig. 5). In the gel, 840 spots were observed for the BS control (Fig. 5A), whereas 2211 spots were observed for the $\mathrm{HCl}$-induced BSGs (Fig. 5B). After the image analysis, we selected spots (342 spots) of the $\mathrm{HCl}$-induced BSGs (Fig. S1) that showed a significant increase or decrease compared with that of the BS control ( $\geq$ twofold, $p<0.05$ ). Of those spots, five spots (\#7113, \#7210, \#8417, \#8808, and \#9205) were of the most increased proteins compared to those of the BS control (Fig. 5C). The five reselected spots were then characterized (Fig. 5D and Table 3). These five proteins were identified as follows: \#7113: succinate-CoA ligase subunit beta (B. subtilis group), \#7210: 30S ribosomal protein S4 (B. subtilis group), \#8417: ATP synthase subunit gamma (Bacillus), \#8808: glycerol-3-phosphate dehydrogenase/oxidase (Bacillus), and \#9505: branched-chain alpha-keto acid dehydrogenase subunit E2 (Bacillus). Detailed information on the protein profiles is presented in Fig. S2. 

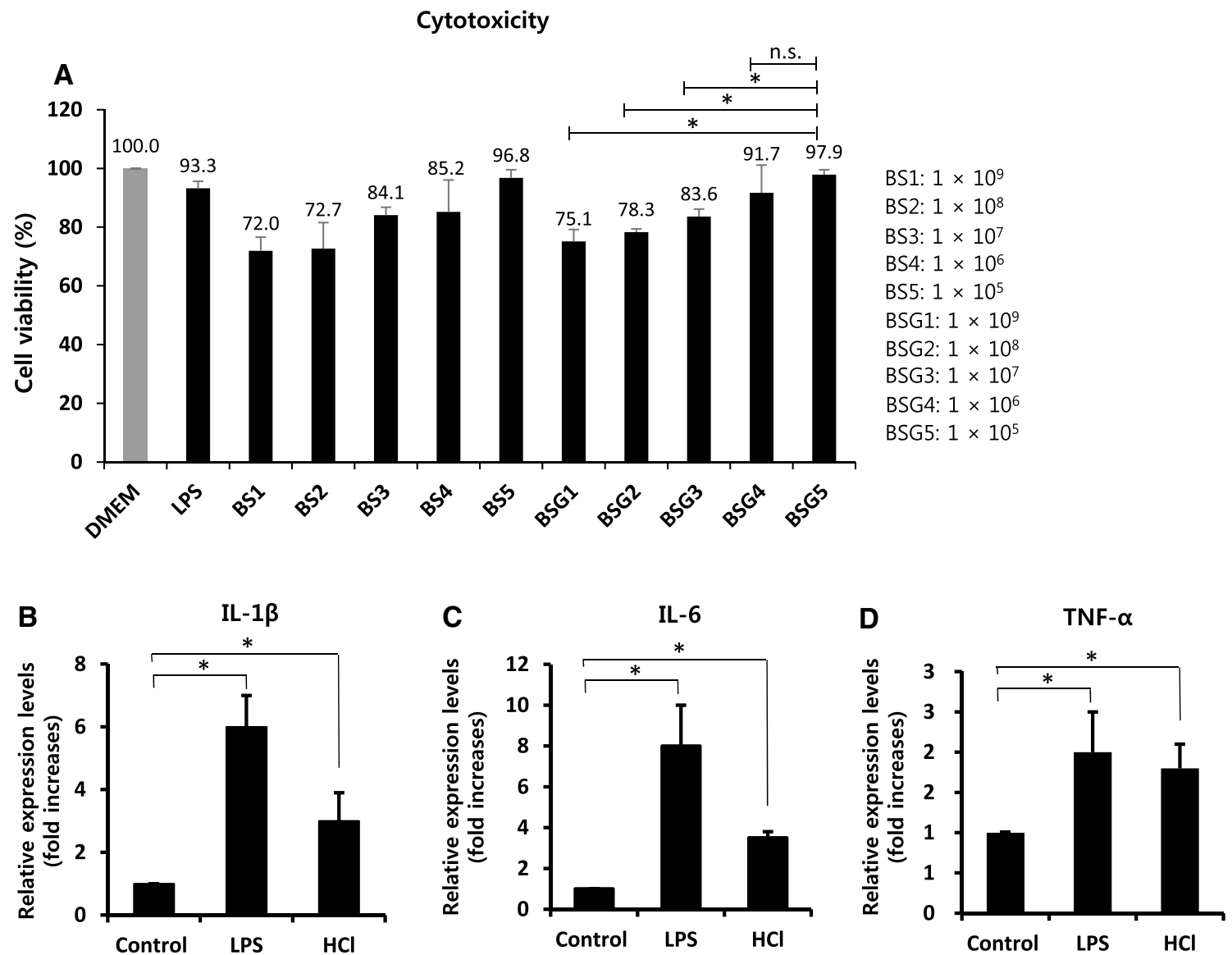

Fig. 3 Cell viability and pro-inflammatory cytokine production in BSG-exposed murine macrophage RAW 264.7 cells. (A) Macrophages were exposed to DMEM, LPS, intact Bacillus subtilis (BS1-5), and BSGs treated with $\mathrm{HCl}$ for 60 min (BSG1-5), respectively. At $24 \mathrm{~h}$ post-exposure, the macrophages were collected for analysis of cell viability, performed using the Cell counting Kit- 8 . Bars represent exposure doses of $1 \times 10^{9}$ (BS1 and BSG1), $1 \times 10^{8}$ (BS2 and BSG2), $1 \times 10^{7}$ (BS3 and BSG3), $1 \times 10^{6}$ (BS4 and BSG4), and $1 \times 10^{5}$ (BS5 and BSG5) $\mathrm{CFU} / \mathrm{mL}$. Absorbance was measured at $450 \mathrm{~nm}$ and all experiments were performed in triplicate. Cytotoxic activity is expressed as the percentage of cell viability using the formula: Cytotoxicity $(\%)=\left(1-A_{450}\right.$ of target cells $/ A_{450}$ of control cells $) \times 100$. The results are based on three independent experiments $(n=3)$. ${ }^{*} p<0.05$ compared with BSG5. (B-D) At $6 \mathrm{~h}$ post-exposure of the macrophages to LPS, intact $B$. subtilis, and $\mathrm{HCl}$-induced BSGs $\left(1 \times 10^{5} \mathrm{CFU} / \mathrm{mL}\right)$ for $60 \mathrm{~min}$, the macrophages were examined for gene expression of cytokines IL- $1 \beta$, TNF- $\alpha$, and IL- 6 using RT-qPCR. The results are based on three independent experiments $(n=3) .{ }^{*} p<0.05$ compared with control. BSG, Bacillus subtilis ghost; DMEM, Dulbecco's modified Eagle's medium; LPS, lipopolysaccharide; $A_{450}$, absorbance at $450 \mathrm{~nm}$; IL- $1 \beta$, interleukin 1 beta; TNF- $\alpha$, tumor necrosis factor alpha; RT-qPCR, quantitative reverse transcription-polymerase chain reaction
Fig. 4 Scanning electron microscopic analysis of BSGs. (A) Untreated control shows intact Bacillus subtilis. (B) Morphology of HCl-induced BSGs. The red circles show the transmembrane lysis tunnels. BSG, Bacillus subtilis ghost
A

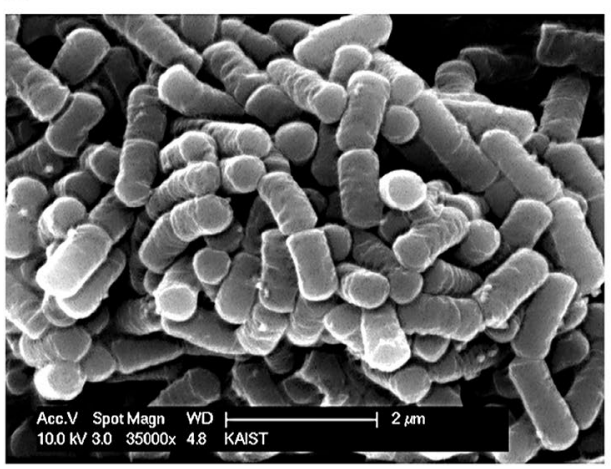

B

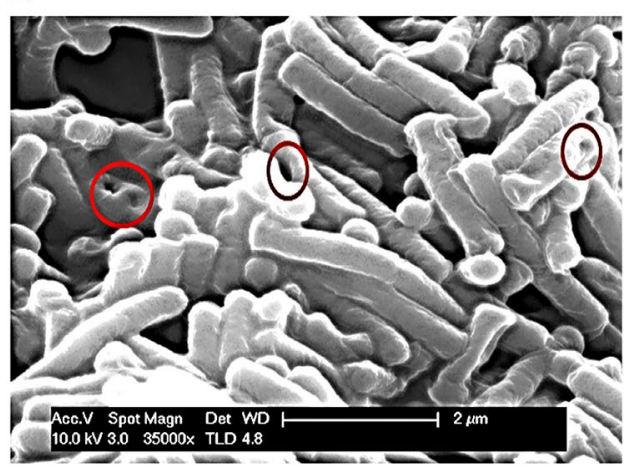




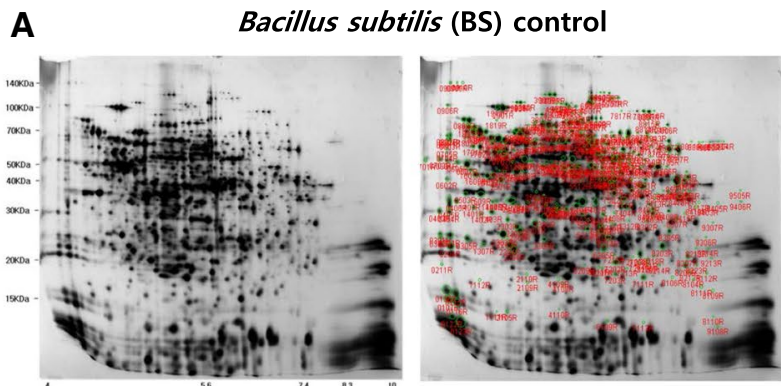

B

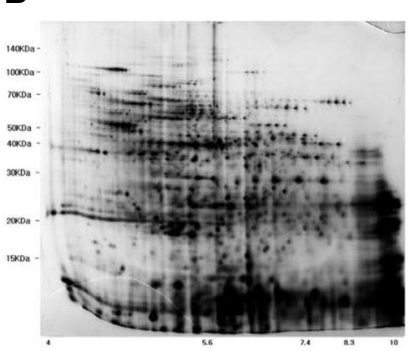

c

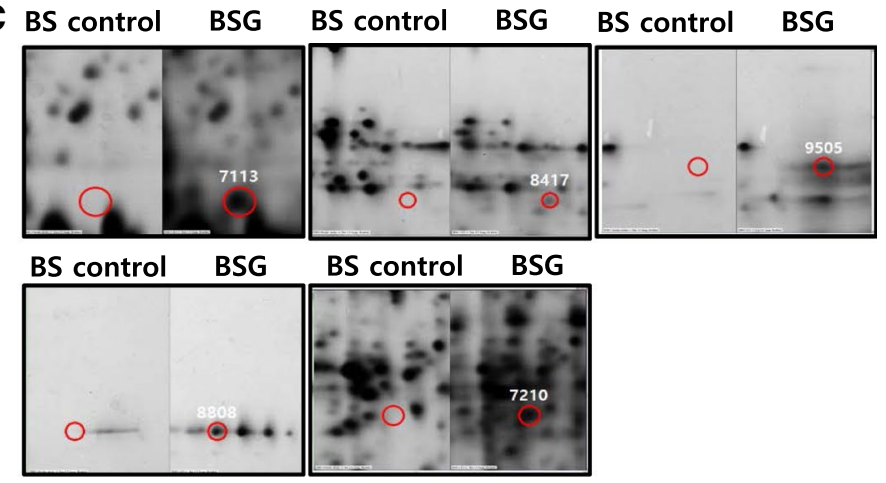

D \# 7113 : succinate--CoA ligase subunit beta [Bacillus subtilis group]

\# 7210 : 30S ribosomal protein S4 [Bacillus subtilis group]

\# 8417 : ATP synthase subunit gamma [Bacillus]

\# 8808 : glycerol-3-phosphate dehydrogenase/oxidase [Bacillus]

\# 9505 : branched-chain alpha-keto acid dehydrogenase subunit E2 [Bacillus]

using MALDI-TOF mass spectrometry. 2-DE, two-dimensional electrophoresis; BS, intact Bacillus subtilis; 2D-PAGE, two-dimensional polyacrylamide gel electrophoresis; BSG, Bacillus subtilis ghost; MALDI-TOF, matrix-assisted laser desorption/ionization-time of flight

(Hajam et al. 2017). The most common method for producing BGs is based on the phage-derived lysis gene $E$ (Zhu et al. 2012; Jawale et al. 2012). However, in addition to being restricted to Gram-negative bacteria, it requires a multi-step process that is expensive and time consuming. Therefore, recent studies have demonstrated an alternative method to produce BGs from a Gram-negative or Grampositive bacterium using the MIC of chemicals, such as $\mathrm{NaOH}$, SDS, and $\mathrm{CaCO}_{3}$ (Vinod et al. 2015; Vinod et al. 2014; Amara et al. 2013; Park, et al. 2016; Amro et al. 2014). Similar to the lysis gene $E$-induced BGs, chemical-induced BGs can form the bacterial cell surface transparent membrane structure. It is relatively easy to make vaccines and/or immunity enhancers using this approach, which reduces production cost and labor compared to that required by the genetic engineering method.

The present study successfully generated Gram-positive BSGs. Particularly, BSGs are prepared according to the method used in the present study where cells are treated and cultured with an MIC of $\mathrm{HCl}$ capable of inhibiting the growth of bacterial colonies of B. subtilis. Additionally, since the BGs are configured such that the shape of the envelope of the cell is intact and the cellular DNA is removed, there is a low risk of adverse effects such as secondary infections due to proliferation, when administered in humans. Of course, B. subtilis is a spore-forming bacterium, and its spores can resist heat and chemicals. However, in the 
course of producing BSG treated with $\mathrm{HCl}$, spore formation was not seen in the photograph of SEM and also there was no colony forming in the plating experiment (for checking whether killed or not) onto the MIC shown in the Fig. 1B. So, there might be no existence of spore materials including sporal DNA. Therefore, BSGs can be effectively used as a vaccine and/or a foreign antigen carrier for the prevention or treatment of infectious diseases caused by Gram-positive Bacillus species.

BGs can stimulate the innate immune system without the addition of exogenous adjuvants; BGs are not regarded as genetically modified organisms and have no genetic material (Wang and Lu 2009; Langemann et al. 2010; Muhammad et al. 2012). Therefore, BGs are expected to be superior in terms of safety, and candidate vaccines were found to be highly immunogenic in several studies (Lubitz et al. 2009; Panthel et al. 2003). Moreover, BGs contain wellknown innate immune stimulating components such as pro-inflammatory cytokines, and have thus potential to act as efficient adjuvants (Huter et al. 1999; Mayr et al. 2005). In this study, we found that $\mathrm{HCl}$-induced BSGs markedly increased the mRNA levels of IL-1 $\beta$, IL- 6 , and TNF- $\alpha$ in murine macrophages, indicating that BSGs are an excellent activator of pro-inflammatory cytokines. In bacterial and viral infections, cytokines play an important role in regulating the host immune system and maintaining the innate immunity (Degre 1996). In the present study, we have confirmed that cytokines are increased by BSGs in macrophages. As inflammation is the basic defense response to various microbial infections (Scheller et al. 1813), we suggest that $\mathrm{HCl}$-induced BSGs have the potential to act as regulators of the innate and adaptive immunity that can defense from bacterial or viral infections. As reported in recent studies, BGs regulate pro-inflammatory factors and chemokines through TLR2 and TLR4 (Quevedo-Diaz et al. 2010; Benko et al. 2008). However, the detailed mechanism of how BSGs increases cytokines in macrophages has not yet been elucidated, further research is needed in future. Furthermore, it is interesting to note that $B$. subtilis elicits an inflammatory response different from that of its diverse BGs produced by different chemical treatments (Hajam et al. 2017; Amara et al. 2013; Lim et al. 2019); therefore, future research in this field should be carried out.

In the present study, by comparing the proteome of the BS control to that of the $\mathrm{HCl}$-induced BSGs using a 2DEbased proteomic approach, we identified five upregulated proteins in the $\mathrm{HCl}$-induced BSGs including succinate-CoA ligase subunit beta, 30S ribosomal protein S4, ATP synthase subunit gamma, glycerol-3-phosphate dehydrogenase/ oxidase, and branched-chain alpha-keto acid dehydrogenase subunit E2. These upregulated proteins are mainly related to protein synthesis and cell metabolism. Most importantly, the metabolic activity of energy and protein synthesis are essential to maintaining life. Therefore, the identified proteins upregulated in the $\mathrm{HCl}$-induced BSGs may greatly influence the immune response in the host. Taken together, all of the above results suggest that $\mathrm{HCl}$-induced BSGs may be able to induce an efficient immune response to Gram-positive Bacillus infectious diseases, and that it may be useful in future development of novel immunomodulatory agents.

Supplementary Information The online version contains supplementary material available at https://doi.org/10.1007/s13273-022-00221-5.

Acknowledgements This work was supported by the Human Resource Training Program for Regional Innovation and Creativity by the Ministry of Education and National Research Foundation (NRF) of Korea (2015035949), and partly by the NRF grant funded by the Korea government (MSIT) (2021R1A2C1008317).

Author contributions Y-MK performed most of the experiments. $\mathrm{K}-\mathrm{SL}$ and W-MK along with MK, H-OP, CWC and J-SH provided idea and designed the study. S-YP and K-SL supervised the project and acquired research funding. All authors were involved in preparing the manuscript.

\section{Declarations}

Conflict of interest Author Young-Min Kim declares that he has no conflict of interest. Author Kwang-Su Lee declares that he has no conflict of interest. Author Won-Mun Kim declares that he has no conflict of interest. Author Min Kim declares that he has no conflict of interest. Author Han-Oh Park declares that he has no conflict of interest. Author Chang Won Choi declares that he has no conflict of interest. Author Joong-Soo Han declares that he has no conflict of interest. Author Shin-Young Park declares that she has no conflict of interest. Author Ki-Sung Lee declares that he has no conflict of interest.

Ethical approval This article does not contain any studies with human participants or animals performed by any of the authors.

Open Access This article is licensed under a Creative Commons Attribution 4.0 International License, which permits use, sharing, adaptation, distribution and reproduction in any medium or format, as long as you give appropriate credit to the original author(s) and the source, provide a link to the Creative Commons licence, and indicate if changes were made. The images or other third party material in this article are included in the article's Creative Commons licence, unless indicated otherwise in a credit line to the material. If material is not included in the article's Creative Commons licence and your intended use is not permitted by statutory regulation or exceeds the permitted use, you will need to obtain permission directly from the copyright holder. To view a copy of this licence, visit http://creativecommons.org/licenses/by/4.0/.

\section{References}

Amara AA, Salem-Bekhit MM, Alanazi FK (2013) Sponge-like: a new protocol for preparing bacterial ghosts. Sci World J 2013:545741. https://doi.org/10.1155/2013/545741

Amro AA, Salem-Bekhit MM, Alanazi FK (2014) Plackett-Burman randomization method for bacterial ghosts preparation form $E$. 
coli JM109. Saudi Pharm J 22:273-279. https://doi.org/10.1016/j. jsps.2013.06.002

Benko S, Magyarics Z, Szabo A, Rajnavolgyi E (2008) Dendritic cell subtypes as primary targets of vaccines: the emerging role and cross-talk of pattern recognition receptors. Biol Chem 389:469 485. https://doi.org/10.1515/bc.2008.054

Degre M (1996) Cytokines and bacterial infections. Biotherapy 8:219228. https://doi.org/10.1007/BF01877208

Eko FO, Mayr UB, Attridge SR, Lubitz W (2000) Characterization and immunogenicity of Vibrio cholerae ghosts expressing toxincoregulated pili. J Biotechnol 83:115-123. https://doi.org/10. 1016/s0168-1656(00)00315-1

Fernandes CJ, Stevens DA, Groot Obbink DJ, Ackerman VP (1985) A replicator method for the combined determination of minimum inhibitory concentration and minimum bactericidal concentration. J Antimicrob Chemother 15:53-60. https://doi.org/10.1093/jac/ 15.1.53

Frosch M, Meyer TF (1992) Transformation-mediated exchange of virulence determinants by co-cultivation of pathogenic Neisseriae. FEMS Microbiol Lett 100:345-349. https://doi.org/10. 1111/j.1574-6968.1992.tb14062.x

Hajam IA et al (2015) Bacterial ghosts of Escherichia coli drive efficient maturation of bovine monocyte-derived dendritic cells. PLoS ONE 10:e0144397. https://doi.org/10.1371/journal.pone. 0144397

Hajam IA, Dar PA, Won G, Lee JH (2017) Bacterial ghosts as adjuvants: mechanisms and potential. Vet Res 48:37. https://doi.org/ 10.1186/s13567-017-0442-5

Huter V et al (1999) Bacterial ghosts as drug carrier and targeting vehicles. J Control Release 61:51-63. https://doi.org/10.1016/ s0168-3659(99)00099-1

Jawale CV, Chaudhari AA, Jeon BW, Nandre RM, Lee JH (2012) Characterization of a novel inactivated Salmonella enterica serovar Enteritidis vaccine candidate generated using a modified cI857/ lambda PR/gene E expression system. Infect Immun 80:15021509. https://doi.org/10.1128/IAI.06264-11

Langemann T et al (2010) The bacterial ghost platform system: production and applications. Bioeng Bugs 1:326-336. https://doi.org/10. 4161/bbug.1.5.12540

Lim $\mathbf{J}$ et al (2019) Harnessing the immunomodulatory properties of bacterial ghosts to boost the anti-mycobacterial protective immunity. Front Immunol 10:2737. https://doi.org/10.3389/fimmu. 2019.02737

Lubitz P, Mayr UB, Lubitz W (2009) Applications of bacterial ghosts in biomedicine. Adv Exp Med Biol 655:159-170. https://doi.org/ 10.1007/978-1-4419-1132-2_12

Mayr UB et al (2005) Bacterial ghosts as antigen delivery vehicles. Adv Drug Deliv Rev 57:1381-1391. https://doi.org/10.1016/j. addr.2005.01.027

Muhammad A, Champeimont J, Mayr UB, Lubitz W, Kudela P (2012) Bacterial ghosts as carriers of protein subunit and DNA-encoded antigens for vaccine applications. Expert Rev Vaccines 11:97116. https://doi.org/10.1586/erv.11.149

Oakley BR, Kirsch DR, Morris NR (1980) A simplified ultrasensitive silver stain for detecting proteins in polyacrylamide gels. Anal Biochem 105:361-363. https://doi.org/10.1016/0003-2697(80) 90470-4

Panthel K et al (2003) Generation of Helicobacter pylori ghosts by PhiX protein E-mediated inactivation and their evaluation as vaccine candidates. Infect Immun 71:109-116. https://doi.org/ 10.1128/IAI.71.1.109-116.2003

Park HJ et al (2016) Characterization of chemically-induced bacterial ghosts (BGs) using sodium hydroxide-induced vibrio parahaemolyticus ghosts (VPGs). Int J Mol Sci. https://doi.org/ 10.3390/ijms17111904

Poudel P, Tashiro Y, Sakai K (2016) New application of Bacillus strains for optically pure L-lactic acid production: general overview and future prospects. Biosci Biotechnol Biochem 80:642-654. https:// doi.org/10.1080/09168451.2015.1095069

Quevedo-Diaz MA et al (2010) Involvement of TLR2 and TLR4 in cell responses to Rickettsia akari. J Leukoc Biol 88:675-685. https:// doi.org/10.1189/jlb.1009674

Rossol M et al (2011) LPS-induced cytokine production in human monocytes and macrophages. Crit Rev Immunol 31:379-446. https://doi.org/10.1615/critrevimmunol.v31.i5.20

Scheller J, Chalaris A, Schmidt-Arras D, Rose-John S (1813) The proand anti-inflammatory properties of the cytokine interleukin-6. Biochim Biophys Acta 878-888:2011. https://doi.org/10.1016/j. bbamcr.2011.01.034

Soromou LW et al (2012) Regulation of inflammatory cytokines in lipopolysaccharide-stimulated RAW 264.7 murine macrophage by 7-O-methyl-naringenin. Molecules 17:3574-3585. https://doi. org/10.3390/molecules 17033574

Stein T (2005) Bacillus subtilis antibiotics: structures, syntheses and specific functions. Mol Microbiol 56:845-857. https://doi.org/10. 1111/j.1365-2958.2005.04587.x

Stickel F et al (2009) Severe hepatotoxicity following ingestion of Herbalife nutritional supplements contaminated with Bacillus subtilis. J Hepatol 50:111-117. https://doi.org/10.1016/j.jhep. 2008.08.017

Tu FP, Chu WH, Zhuang XY, Lu CP (2010) Effect of oral immunization with Aeromonas hydrophila ghosts on protection against experimental fish infection. Lett Appl Microbiol 50:13-17. https:// doi.org/10.1111/j.1472-765X.2009.02746.x

van Dijl JM, Hecker M (2013) Bacillus subtilis: from soil bacterium to super-secreting cell factory. Microb Cell Fact 12:3. https://doi. org/10.1186/1475-2859-12-3

Ventola CL (2015) The antibiotic resistance crisis: part 1: causes and threats. P T 40:277-283

Vinod N et al (2014) Chemically induced Salmonella enteritidis ghosts as a novel vaccine candidate against virulent challenge in a rat model. Vaccine 32:3249-3255. https://doi.org/10.1016/j.vaccine. 2014.03.090

Vinod N et al (2015) Generation of a novel Staphylococcus aureus ghost vaccine and examination of its immunogenicity against virulent challenge in rats. Infect Immun 83:2957-2965. https:// doi.org/10.1128/IAI.00009-15

Vinod N et al (2017) A Salmonella typhimurium ghost vaccine induces cytokine expression in vitro and immune responses in vivo and protects rats against homologous and heterologous challenges. PLoS ONE 12:e0185488. https://doi.org/10.1371/journal.pone. 0185488

Wang X, Lu C (2009) Mice orally vaccinated with Edwardsiella tarda ghosts are significantly protected against infection. Vaccine 27:1571-1578. https://doi.org/10.1016/j.vaccine.2009.01.002

Zhu W, Yang G, Zhang Y, Yuan J, An L (2012) Generation of biotechnology-derived Flavobacterium columnare ghosts by PhiX174 gene E-mediated inactivation and the potential as vaccine candidates against infection in grass carp. J Biomed Biotechnol 2012:760730. https://doi.org/10.1155/2012/760730

Publisher's Note Springer Nature remains neutral with regard to jurisdictional claims in published maps and institutional affiliations. 